\title{
Hybridization as Global Cultural Production Strategy: A Case Study in Disney Animation
}

\author{
Jianling Wang \\ School of Communication \\ Yunan Normal University \\ Kunming, China 650500
}

\begin{abstract}
By tracing back the hybridization tradition in the early and classic Disney animation production, this study examines the new hybridization characteristics of Disney animation under the globalization context. It also attempts to illustrate that hybridization has become the ongoing integral trend in cultural production with both globalization and localization of the culture industry, and to shed light on the development of Chinese animation industry in globalization context.
\end{abstract}

Keywords-hybridization; globalization; deculturalization; reculturalization; disney animation

\section{INTRODUCTION}

Globalization is one of the most important characteristics of the late 20 th century and the early 21 st century. The tide from the economic field also rapidly spreads to many fields such as society and culture. Globalization is regarded as a process, a reality and faith $1^{1}$. People hold different attitudes to its nature. Giddens thinks the nature of globalization is the modernity of flow. Flow includes the movement that surpasses space and time of material products, population, signs, symbols and information ${ }^{2}$. Custer thinks globalization is the compression of time and space. Globalization makes human society become a society with real-time interaction ${ }^{3}$.

People hold different attitudes toward the influence of globalization, especially the influence of culture. Roland Robertson proposes the concept that "the world is a single place" ${ }^{4}$. Ulf Hannerz also thinks a world culture exists now ${ }^{5}$. Behind the pessimistic voice, many scholars think the globalization of economy does not bring the globalization of culture, and new cultural forms and connections produce in

Mattelart, A. An Archaeology of the Global Era: Constructing a belief. Media Culture \& Society, 2002, 24: 591-612.

Xue Xiaoyuan, Cao Rongxiang. Globalization and Cultural Capital. Beijing: Social Sciences Academic Press, 2005, page 3 Manual Castells. The Rise of the Network Society, Beijing: Social Sciences Academic Press, 2006

Robertson, Roland. Globalization: Social theory and global culture. London: Sage, 1992:23-24.

Quoted from John Tomlinson. Globalization and Culture. Nanjing: Nanjing University Press, 2004, page 104 the continuous fusion process ${ }^{6}$. Hybridization becomes the most important way to produce new cultural forms and elements. The concept that "the globalization-based culture is hybrid culture" 7 is even proposed directly. As the important characteristic of cultural production under the globalization context, hybridization becomes the inexorable trend and rule of modern cultural production.

\section{HYBRIDIZATION: CULTURAL LOGIC IN THE AGE OF} GLOBALIZATION

In the discussion of globalization and culture, hybridization attracts people's extensive attentions and becomes "the cultural logic in the age of globalization" because of its constructive connotation on politics, economy and culture. ${ }^{8}$ The hybridization originated from biological image at first refers to the biological hybridization of species or human beings. In the late 19th century, with the beginning of imperialism colonial rule, the word hybridization entered the language field, referring to the hybrid fusion of different languages and dialects. In the cultural field, hybridization refers to the fusion of different cultural elements and forms and the new cultural forms and connotations produced in this process. Homi Bhabha calls the discourse space formed under the influence of local culture and culture of colonized areas as the third space. Hybridization opens "the third

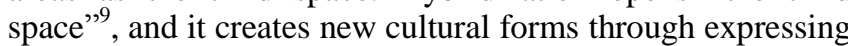
discourse and contents that are different from the local cultural space and colonial cultural space. James Lul observes hybridization is the nature of contemporary cultural activities. "Cultural hybridization turns the existing cultural materials and codes into more delicate matters and discussing themes and reappearance through routine communication exchange, and then integrates those forms with other forms" ${ }^{\prime 10}$. The concept of hybridization explains

6 Arles Boole. Global Revolution: Politics, Economy and Culture in the Age of Globalization. Beijing: Social Sciences Academic Press, 2001, page 6

John Tomlinson. Globalization and Culture. Nanjing: Nanjing University Press, 2004, page 205

8 Kraidy, Marwan.M. Hybridity or the Cultural Logic of Globalization. Philadelphia, PA: Temple University Press, 2005:149.

9 Sheng Anfeng, Homi Bhabha. Research on Postcolonial Theory. Doctoral thesis of Beijing Language and Culture University, 2004, page 28

10 James Lull. Culture in the Communication Era. Taipei: Weber Publication International Ltd., 2005, page 202 
the sophistication in the process of forming human culture, "culture does not contain any pure zone, because it experiences the ceaseless and cross-cultural process" $" 11$. In reality, the development of culture is essentially flowing and dynamic, referring to the process of accepting or rejecting elements under the interaction of different forces, so hybridization becomes one of the ways of producing culture.

The construction of hybridization that combines diversified cultural elements reflects the equal dialogical relationship of different cultures. The whole combination process has "the equal degree and some opportunity"12. The equal dialogical relationship has dispelled the linear mode of thinking of cultural imperialism from western countries to global scale since the 1960s and 1970s, and it removes the limit between center and edge and the polarization thinking of other forms. Homi Bhabha says hybridization opens his so-called third space. Components of this space continuously conduct mutual exchange. They are field domains that resist imperial power and deprive the authority and its authenticity of imperialist culture in the power system. Edward Said also observes hybridization mixes different cultures, and the rebel energy produced challenges the central dominant cultural norms through all the disturbances and confusions in the separable fuzzy space ${ }^{13}$. Therefore, when the global hegemony politics attempts to normalize and define itself and consolidate the legality of its hegemony through combining cultural symbols and unifying social practices, the standpoint of recognizing otherness and supporting cultural dialogue avails treating various cultural identities and changing unipolar politics.

Under the tendency of the globalization of cultural industry, hybridization has more constructive connotations and becomes important production mode of cultural products as well as conforms to the production principles in the cultural industry under the background of globalization. From the perspective of culture, hybridization has enriched creative materials and opened new cultural forms and elements. From the perspective of industry, the high risk of cultural industry determines enterprises shall take strategies like star system and type film, in order to reduce market risk. Hybridization also becomes an important strategy for enterprises of cultural production, especially transnational cultural enterprises to conduct content production. To obtain the maximum profit, cultural products of these enterprises often conduct target positioning and marketing in the global market. The production of cultural products requires us to remove or neutralize contents and forms of our own side that cannot be accepted by cultures of other sides, namely deculturalism, at the same time bring in or accept forms of the cultures of other sides, namely re-culturalism. Cultural products produced through hybridization just remove contents and forms that cannot or not easily be accepted by target customers, and absorb forms that they can and easily

\footnotetext{
11 John Tomlinson. Globalization and Culture. Nanjing: Nanjing University Press, 2004, page 210

12 John Tomlinson. Globalization and Culture. Nanjing: Nanjing University Press, 2004, page 211

13 Edward Said .Culture and Imperialism, London : Chatto \&Windus, $1993: 406$.
}

accept. It is similar to the situation that the promotion and sale of products in transnational corporations in other places around the world need to involve "removing the cultural characteristics of the place of origin" and "suiting the culture of sales area"14. With the development of globalization, the hybrid production adopted by cultural enterprises conforms to the modern characteristics of global flow, and the operation of cultural symbols and resources that surpass time and space is increasingly frequent.

Since hybridization becomes an important characteristic of the cultural production in the age of globalization, problems such as which cultural elements shall be retained, what are abandoned and why they are abandoned in using hybridization are inescapable. The clarification of these problems has practical guiding significance on the development of cultural industry in our country. As the most successful cultural entertainment group in the world, products of the Disney Company have provided excellent viewpoints for us to thoroughly discuss "how to conduct cultural production through hybridization".

\section{IMITATION: DISNEY COMPANY'S HYBRIDIZATION STRATEGY IN EARLY STAGE}

Recalling the history of the Disney Company in animation production, we can easily find imitation is always the most important strategy of content production of the Disney Company. Except for few original works such as series of Mickey Mouse and Donald Duck, Lilo \& Stitch, Dinosaur, most of the works are adapted from fairy tales, folklores or masterworks of various countries in the world. From the late 1920s to 1930s, the main way for the Disney Company in hybridization production is imitation, and European cartoon and silent comedy at that time. Because the target audiences at that time are mainly from Europe and have the same culture with the imitated object, the deculturalism and re-culturalism in hybridization are not very obvious in Disney Company in this period. They often directly imitate contents and forms. For example, in the Steamboat Willie of early Mickey Mouse series (1928), we can see many comedy elements of Chaplin. The modeling of the two presents cartoon-type exaggeration. Mickey wears top hat and extra-large boots, which directly imitates the modeling of Chaplin as "a small vagrant", top hat, loose pants, cane and extra-large shoes. In regard to the content, both of them present the lowliness and self-mockery of nobody in facing powerful opponents. On comedy style, both of them absorb the exaggerated and rapid actions in comedies, letting audiences laugh a hearty laugh in "taking pleasure in their misfortune" and presenting the heroism in nobody. "Chaplin is undoubtedly the most important chief source of Mickey... the way that Mickey and his partners

14 He Ping, Chen Guoben. Analysis on Several New Concepts in Cultural Research in the Age of Globalization. Shandong Social Science, 2005, 10: 23-28 
entertain audiences in the audio era is the same with that used by Chaplin to entertain the last generation"

Disney classics from the late 1930s to 1970s are mainly adapted from literatures of European fairy tales and legends, but the period feel and practical significance are obviously strengthened. The re-culturalism of animation products obviously highlights. During this period, Disney created master works such as Snow White and the Seven Dwarfs (1938), Pinocchio (1940), Cinderella (1950) and Sleeping Beauty (1959). The spirit of original work remains unchanged, but the addition of supporting roles strengthens the dramatic conflict of animation, creates the lively comedy atmosphere and brings elements of the time in the animation. Like in the original work, the Snow White is sweet, industrious and kind-hearted. The queen is still vicious. But the Seven Dwarfs have names and distinct characters, especially the role of "Stubborn". At first, he strongly opposes to take in the Snow White because he is afraid of trouble, but he likes the Snow White most afterwards. The petty tricks played by him to kiss the Snow White again let the audiences burst their sides with laughter, at the same time reflect the kindness of the Snow White. The animation Sleeping Beauty also basically remains the same as the original work but adds the plot that the prince takes the initiative to find the Sleeping Beauty in the Black Witch Castle. To meet the Sleepy Beauty and get a satisfactory love, he has to overcome difficulties and obstacles. In the original work, the prince comes across the Sleepy Beauty when he strolls in the forest, and he saves her through kissing her slightly. However, after the adaptation of Disney, the pursuit of love is not waiting and the fairytale love story is more profound and runs over with the spirit of the times.

The Disney animation in early and classic periods basically takes imitation as the main approach of hybridization production. Because European and American cultures are traced to the same origin, in the creation of hybridization, Disney basically follows its original appearance and themes. The re-culturalism is only embodied in the supplement of some rich details that manifest characters' personality and humorous segments of supporting roles. In the late 20th century with global integration and cultural industrialization, when Disney expands the audiences of its products from Europe and America to the whole world, the above hybridization obviously has failed to meet the new market demands.

\section{DE-CULTURALISM AND RE-CULTURALISM IN ADAPTATION: DISNEY'S STRATEGY OF HYBRIDIZATION IN THE AGE OF GLOBALIZATION}

The globalization tendency is increasingly obvious in the 1980s. After the development of half a century, the animation technology of Disney advances rapidly. It has the ability of playing complicated stories and reveals vigorous original ability. The global flow of cultural symbols and resources endows Disney Company with abundant creativity.

15 Finch, Christopher. The Art of Disney: From Mickey Mouse to the Magic Kingdoms [M].New York, NY: Harry N. Abrams, Inc., Publishers. 2004:46-47.
At the meantime, the company also needs to expand the market outside Europe and America. The application of hybridization, a way of cultural production, is more frequent and bolder. The de-culturalism and de-culturalism become the largest characteristics of the hybridization production of Disney under the background of globalization.

In the age of globalization, de-culturalism is the key for the cultural products of Disney to enter the global market. Instance Mulan produced by Disney, through de-culturalism, the traditional values of benevolence, righteousness, courtesy, wisdom and trust contained in the original work, the ethnic contradictions in Chinese history and the social reality that females are in the subordinate position in feudal society are faded or hidden, because the deep-seated national psychology, values and totally different social development will easily cause barriers to cross-cultural communication and are not beneficial to increase the entertainment of animation. So to speak, through de-culturalism, the original work only provides a background for Disney to tell the story and an illusory time and space. The narration and affective logic are written by Disney, the master of making up stories. Therefore, de-culturalsim makes the animation first present the phenomenon of cultural hollow. Besides, works with the cultural hollow possess no obvious cultural characteristics but the romantic and adventurous stories happened in the illusory time and space. This kind of story is irrespective of social class, gender and race.

Cultural hollow means the beginning of hybridization. Firstly, the hybridization production of Mulan retains some background symbols in Chinese culture, such as mist-filled celestial mountains, weeping willow, pagoda and ancient Chinese articles of clothing. These scenes conform to the fantasy of western people for the East. The creation of exoticism can catch eyes of the western audiences. Secondly, dubbers of different nationalities embody the cultural pluralism in producing the animation, including Wen Mingna, the dubber of Mulan, Eddie Murphy, the dubber of Mush and dubbers of other nationalities. The ethnic Chinese dubber appeals to Chinese audiences. The role and dubbling of Eddie Murphy not only strengthens the entertainment of the film but also inherits the humorous style of Disney. Disney completes the preliminary hybridization through absorbing the background elements in different cultures.

The re-culturalism of Mulan introduces the brand personality of Disney "Extraordinary Joys Touch the Heart" 16. The protagonist appears in a series of misunderstanding and noise, which is the watercooler moment commonly used in the comedic animations of Disney in early stage. However, the prologue of the original work the Ballad of Mulan is "One sigh after another, Mulan sat opposite the door weaving". Mulan is weaving, which is the work of the traditional Chinese females. She is a dutiful, gentle and quiet traditional Chinese female and is compelled to join the army superseding her father, which embodies the filial piety. In the version of Disney, Mulan has characteristics of modern Disney heroine: She is vivacious,

16 Guan Kejiang. Interviewing Disney President, Exploration on the Child Interest in Adults' Heart. Global Times, Sept.28, 2007(17) 
naughty and curious about the outside world. She is discontented with her lot, which doesn't meet the standard of a clever wife and wise mother in Chinese tradition, so she fails the test in being a clever wife and wise mother and doubts herself. Mulan joins the army superseding her father to prove his existence value and firmly shows the true self. In this way, the theme of filial duty in the original work is rewritten by Disney as the modern theme that females pursue and affirm themselves. The ending naturally becomes the classic happy reunion of Disney and all shall be well. The pursuit and affirmation of self, the victory of self-will and the success of nobody surpass the national boundaries and easily touch people's heart because of its universal value.

Hybridization provides story materials for Disney. Through de-culturalism, Disney retains the superficial background symbols of stories and removes the deep-rooted difference in cultural values, successfully eliminates the disturbance of cross-cultural comprehension. De-culturalism endows the product with universal values such as love, selfvalue and personal success. Disney launches the products all over the world and wins favor of audiences worldwide and also makes a lot of money.

\section{CONCLUSION}

The animation in our country must break through the present predicament that "industry isn't accompanied by culture" and "culture isn't accompanied by creativity"(1). We must think about the nature of industry and the production rules. Especially under the background of the age of globalization, the cultural industry integrates globalization and localization. Hybridization has become the inexorable trend and production rules of modern cultural production.

The TV industry in China under the globalization context must first realize hybridization is an important way of cultural production in the age of globalization and the inevitability of conforming to the production law. Hybridization enriches the materials of cultural production and diversifies the gene of cultural products. It avails the entrance of global market and improves the competitiveness and influence of cultural products. After TV powers such as America, Japan and Korea complies with the law of cultural products, the vitality of cultural innovation is continuously strengthened, presenting a new appearance in front of audiences. In recent years, foreign TV production accelerates the hybridization of traditional Chinese culture, and many TV products with the background of Chinese stories emerge in large numbers. Similar to modern products of Disney, these products retains elements that present ancient Chinese culture, make up stories of their own and bring in values totally different from the original work through deculturalism and re-culturalism. Avatar: The Last Airbender broadcasted on Nickelodeon in 2007 presents the old and mysterious Chinese culture. The prelude starts with five elements of metal, wood, water, fire and earth. A Chinese hero that saves the world is shaped along with Chinese kungfu that dazzles the eyes, ancient Chinese characters, the music from xiao, a vertical bamboo flute. The same hybridization commonly appears in Japanese and Korean animation. The Dragon Ball, a Japanese TV animationm, draws materials from the Journey to the West of China. The difference is that the Sun Wukong and seven dragon balls that can fulfill people's expectations take readers from mountain villages to cities, from the earth to alien planet and from the present to the future. Nevertheless, it still wins favor of Chinese audiences who love animation and becomes one of the most popular sixteen animation images ${ }^{17}$.

After realizing the importance of hybridization, the way of cultural production, in the globalization background, the animation production in our country should develop the spirit of borrowlism and actively absorb different traditional Chinese cultural elements and learn foreign animation production. Except for industrial mode, marketing and technology, it's necessary to absorb and mix the cultural elements of foreign countries. To sum up, nowadays, hybridization has become a way of global cultural production. In order to realize the revitalization of Chinese animation, we have to make the past serve the present, make foreign things for Chinese use and realize bold hybridization.

\section{REFERENCES}

[1] Edward Said .Culture and Imperialism, London: Chatto \&Windus $1993: 406$

[2] Finch, Christopher. The Art of Disney: From Mickey Mouse to the Magic Kingdoms.New York, NY: Harry N. Abrams, Inc., Publishers. 2004:46-47.

[3] Kraidy, Marwan.M. Hybridity or the Cultural Logic of Globalization. Philadelphia, PA: Temple University Press, 2005:149.

[4] Mattelart, A. An Archaeology of the Global Era: Constructing a belief. Media Culture \& Society,2002, 24: 591-612.

[5] Robertson, Roland. Globalization: Social theory and global culture London: Sage, 1992:23-24.

[6] Arles Boole. Global Revolution: Politics, Economy and Culture in the Age of Globalization. Beijing: Social Sciences Academic Press, 2001

[7] Guan Kejiang. Interviewing Disney President, Exploration on the Child Interest in Adults' Heart. Global Times, Sept.28, 2007(17)

[8] He Ping, Chen Guoben. Analysis on Several New Concepts in Cultural Research in the Age of Globalization. Shandong Social Science, 2005, 10: 23-28

[9] Li Siqu. Digital Entertainment Industry [M], Chengdu: Sichuan University Press, 2006: 184-185

[10] Li Siqu. Research on the Development Strategy of China's Digital Entertainment Industry, Beijing: Social Sciences Academic Press, 2007: 135

[11] Manual Castells. The Rise of the Network Society, Beijing: Social Sciences Academic Press, 2006

[12] Sheng Anfeng, Homi Bhabha. Research on Postcolonial Theory. Doctoral thesis of Beijing Language and Culture University, 2004, page 28

[13] Xue Xiaoyuan, Cao Rongxiang. Globalization and Cultural Capital. Beijing: Social Sciences Academic Press, 2005, page 3

[14] John Tomlinson. Globalization and Culture. Nanjing: Nanjing University Press, 2004, page 104

[15] James Rull. Culture in the Communication Era. Taipei: Weber Publication International Ltd., 2005, page 202

17 Li Siqu. Digital Entertainment Industry [M], Chengdu: Sichuan University Press, 2006: 184-185 